\title{
Rebuilding Greece, 1830-1920. Ambitions and Realities
}

\author{
Dora Monioudi-Gavala \\ University of Patras, Patras, Greece \\ Email:dmoga@upatras.gr
}

How to cite this paper: Monioudi-Gavala, D. (2019). Rebuilding Greece, 1830-1920. Ambitions and Realities. Advances in Historical Studies, 8, 199-214.

https://doi.org/10.4236/ahs.2019.85015

Received: October 11, 2019

Accepted: December 6, 2019

Published: December 9, 2019

Copyright (c) 2019 by author(s) and Scientific Research Publishing Inc. This work is licensed under the Creative Commons Attribution International License (CC BY 4.0).

http://creativecommons.org/licenses/by/4.0/ (c) (i) Open Access

\begin{abstract}
The built areas of cities saw intense activity in the new Hellenic state established in 1830, after the war of Independence from Ottoman rule. State activity had highly significant results, which changed the country's constructed environment, transforming ruined communities, or insignificant villages into urban centres. Although the state's goals are known through the bibliography to date, the reasons for its successes and failures have been of minor concern. This study analyzes the factors that contributed to the state's success or failure in planning constructed space. It also endeavours to estimate the effects of the changes in people's lives that could be defined as cultural.
\end{abstract}

\section{Keywords}

Urban Planning, Architecture, Greece, Athens, Nineteenth Century

\section{Introduction}

Greek cities provide interesting expressions of town planning in the city's history. They lived through the long period of Ottoman rule from the fifteenth to the nineteenth-twentieth century, the War of Independence (1821-27) (Dakin, 1973), after which they were incorporated into in the new Hellenic state (Diamandouros, 1972; Dertilis, 2009). The historic adventures, including periods of wartime events and disasters ${ }^{1}$ as well as eras of safety and progress, created an interesting palimpsest on the constructed space.

When the three protecting powers (Britain, France and Russia) proclaimed Greece an independent state in the Protocol of London (1830), its communities were either in ruins as a result of wartime events, or were inconsequential villag${ }^{1}$ The disasters included the blowing up of the Parthenon on 26 Sep. 1687, after the bombing of the Acropolis and the explosion of a gun powder shed during the siege by the Venetian Francesco Morosini. 
es. The new state aimed to reorganize constructed space by replacing sections destroyed and building new settlements. Community reorganization began during the brief period of Kapodistrias' government (1828-31), and became systematized during the reign of Otto $(1833-62) .^{2}$ The intention of the state under Otto's reign (Petropulos, 1968) was to focus on reorganizing the initial geographical area of the new state, of Old Greece (which included the Peloponnese, Sterea Hellas and the islands of the Argosaronic Gulf, the Cyclades and the Sporades) gave the researcher an image of how town planning policy was created "from above" and "from zero" (Monioudi-Gavala, 2012: pp. 197-198), at least during the early decades. The aim of this article is to show the major changes that were made (or not made despite having been planned) in Greek cities and to investigate why they were made, using research tools to reveal the conditions under which the changes took place (Yerolympos, 1996; Kafkoula et al., 1990). ${ }^{3}$ The terms and conditions of the prerequisites that shaped the built environment are analyzed. The object of this study is to explain the significant features of the change in Greek cities, from the pre-revolutionary model to its more modern form. At the same time, the local survivals of the pre-revolutionary model that was preserved until the last decades of the nineteenth century are presented and interpreted.

This study extends from the establishment of the modern Greek state in 1830, until just before the years 1922-23, when the defeat of the Greek army in Asia Minor, the resulting Asia Minor Disaster (Llewellyn Smith, 1973) and the obligatory exchange of populations on both sides of the Aegean ${ }^{4}$ led to a massive wave of almost 1.5 million refugees (Pentzopoulos, 1961), thereby increasing the population of Greece significantly and requiring major changes in constructed space.

\section{Great State Ambitions vs. Actual Capabilities}

The Bavarians reached Greece in 1833 with great ambitions for organizing the new state and deciding to carry them out. They also had major opportunities to realize their ambitions, thanks to the political regime of the absolute monarchy that gave the king full power and the economic capability ensured by the loan of 60 million French francs that were contributed to the new kingdom, to the military power of the salaried army.

Space in the cities was the primary field of reorganization. The state sought to increase the population (Bikelas, 1868) ${ }^{5}$ and to create cities capable of developing urban functions; it succeeded in both these goals. The main means was legislation, ${ }^{6}$ the regulations of which were imposed in an autocratic and pedagogical ${ }^{2}$ The three great powers placed Otto, son of Ludwig I of Bavaria and at that time a minor, on the throne of Greece. His reign, until he came of age, was undertaken by a regent.

${ }^{3}$ The issue has been discussed in the bibliography since the ' 80 s with conferences and in scientific studies.

${ }^{4}$ The obligatory exchange of populations was agreed upon in the Treaty of Lausanne, 1923.

${ }^{5}$ The first population census (1834) recorded 650,000 inhabitants. 
way: it is typical that one of the first royal decrees of the new state concerned the penalties imposed by the police in the event of building violations. ${ }^{7}$ The legislation was sufficient, with noteworthy coherence, and obligatory observance. It covered successfully the reform of constructed space in such a way that it could not be overthrown. It was distinguished for its stability, and with some additions, it regulated the reconstruction of Greece until 1923, when the housing needs of thousands of refugees required reforms. Another main state method was town-planning: the number of cities for which plans were approved by royal decrees was impressively large. Large-scale changes were planned from the beginning of Otto's reign. They concerned the very structure of the city. The city built under Ottoman rule that the Hellenic state "inherited" did not have time to undergo the modernizing processes that evolved in the Ottoman empire during the nineteenth century, especially during its second half, and changed both large and small cities to a greater or lesser degree The reforms of the Tanzimat era were associated with the new legislation (Aristarchi, 1873), and changed governance, segregated social groups and their activities, as well as town planning and architecture. Among many other things, they influenced the cities that were included in the Hellenic State either in 1881 (Volos, Larissa), or during the Balkan Wars in 1912-13 (Thessaloniki, Ioannina, Chios, etc.) (Karadimou-Yerolympou, 1997; Anastassiadou, 1997; Monioudi-Gavala, 2004). The most significant changes in constructed space were the re-designing and rebuilding of markets after fires, the limited scale of the city's redesigns etc. On the contrary, the city inherited from Ottoman rule in the initial area of the Hellenic state, i.e. Old Greece, was a pre-modern city. Its constructed space had the particular features of the local conditions under which it was built and, more generally, its irregular road network with narrow, curving streets that changed width and usually wound up in dead ends, the traditional markets (bazaars), and the lack of water networks and plumbing. This pre-modern town was gradually replaced by a city of the Hellenic state, designed, regular and healthy following European cultural models. A new urban plan was determined with straight streets, a steady width and geometrically designed squares: formalistic Europeanism replaced the long-term (spontaneous) evolution.

Town planning activity in the new Hellenic state was related to two main categories of interventions: those done in existing cities and, by contrast, those carried out in new cities. There were a great many in both categories (Moniou${ }^{6}$ The main legislative tool for organizing the cities was the Royal Decree of 1835 "Regarding the healthy construction of cities and towns", which was in force until 1923. Among the features of the plans, it defined straight roads that usually met at a right angle, squares distributed throughout the city with geometric shapes and not excessively large. It promoted the creation of public space in the cities, with a significant role played by the main squares. It defined the placement of churches and public buildings in the centre. It also foresaw sites for troublesome uses outside the community. It imposed underground networks for water supplies and sewage. It made police permission obligatory for industrial installations and a construction permit for building.

${ }^{7}$ Royal Decree, Government Gazette 10, 1833 "Regarding police penalties for offences and violations of laws regarding public cleanliness, food and construction sites”. 
di-Gavala, 2012). In the existing cities, extensions were made based on the building of new neighbourhoods, as well as the "improvement" of old regions by extending, creating and straightening roads. New towns were built with a plan from the beginning. Most new towns were built as synoekismoi (settlements). They were located in regions where the state owned land, based on a simple mechanism: the state ceded land free of charge, or sold lots at a low price to future settlers on the precondition that they would build on and settle in them within a specified period of time. They were established for the settlement of Greeks from regions under Ottoman rule or of the population that was obliged to move during the war, in order to settle people who would develop financial activity (the port communities in the northwest Peloponnese which served the export of raisins), for moves caused by natural disasters (earthquakes), for moves of settlements in order to conduct excavations (Delphi) etc. One essential difference is noted between the pre-existing villages and synoekismoi: the latter were built from the outset on the basis of an approved plan.

The Kleanthis and Schaubert plan, ${ }^{8}$ the first plan for Athens (Figure 1), was an inspired planning solution, which paid attention to the city's public space and to buildings for public use (Travlos, 1960; Biris, 1966; Papageorgiou-Venetas, 2001; Bastea, 2000; Karidis, 2014; Tsiomis, 2017), with the possible transfer of the ideas of the famous Prussian architect Karl Friedrich Schinkel in shaping it (Karidis, 2019). The ambition of Kleanthis and Schaubert was to make Athens a "vision of classicism": a city with straight lines, symmetry, an attractive geometrical composition, and a network of streets and squares. The Kleanthis and Schaubert plan was modified by the von Klenze plan (Papageorgiou-Venetas, 2000). In any case, the plans of most Greek cities were characterized by the search for a practical solution and not by aiming for a geometrically attractive design. These plans included ambitious expectations since, as a rule, the widening that took place was many times larger than in the existing city.

The incorporation of new territories into the nation in 1864 and 1881 was followed by a number of plans for their cities. ${ }^{9}$ After 1864, and the annexation of the Ionian islands, plans were approved for their settlements usually for extensions (Lixouri, Sami, Ithaki, Corfu). After 1881 plans were approved for cities in Thessaly and part of Epeiros (Karditsa, Larissa, Volos, Arta). The plans were typically characterized in the decrees as diagrams of "straight boundaries", emphasizing the desired straightening, even in the title.

The ambitions of the state were considerably limited by real difficulties. The designs exceeded the capabilities of the Greek kingdom, since the funds required for financial and human purposes were not available. The loan of 60 million

${ }^{8}$ The architects Stamatis Kleanthis (1802-62) and Eduard Schaubert (1804-60) were both graduates of the Berlin Baukademie. The Kleanthis and Schaubert plan provided for public buildings similar to those of other European cities.

${ }^{9}$ The territorial expansions of the new Hellenic state in the nineteenth century affected the Ionian islands (1864), Thessaly and part of Epeiros (1881). During the Balkan wars in 1912-13 Ottoman rule terminated in the remaining part of Epeiros, Macedonia and the northeastern Aegean islands. 


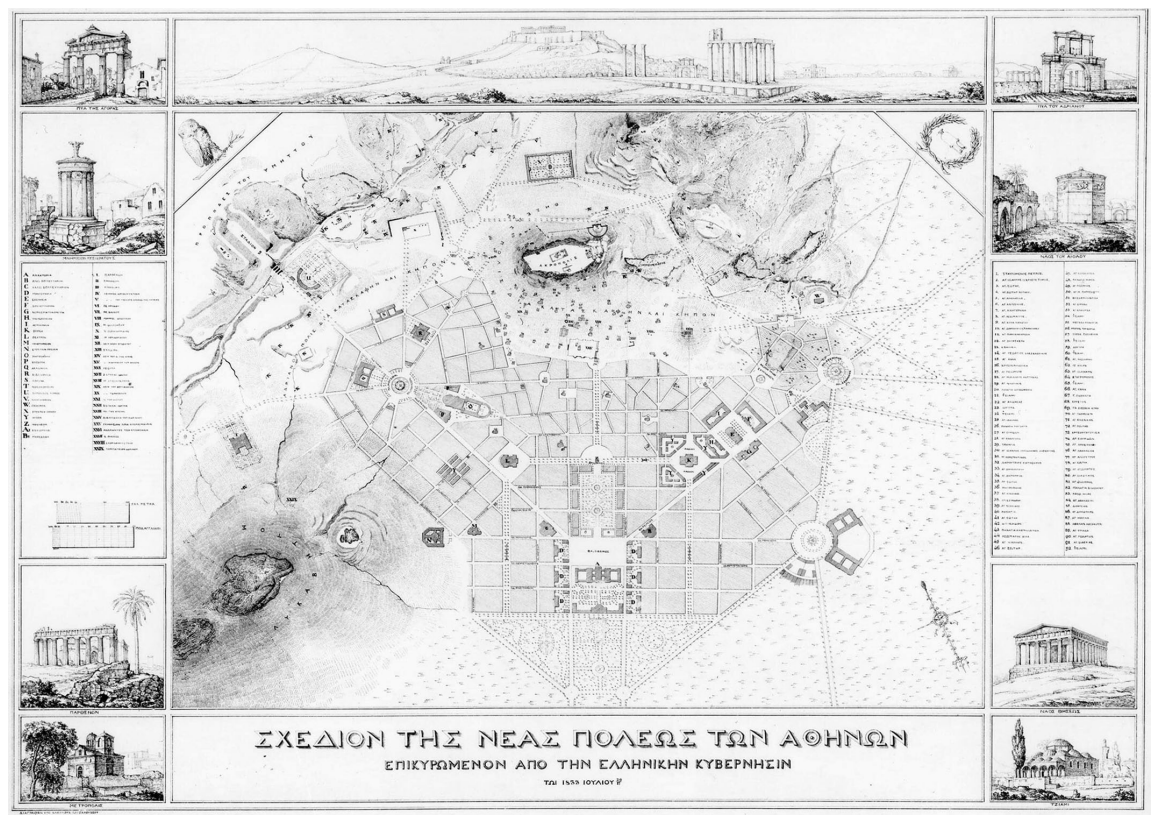

Figure 1. The Kleanthis and Schaubert plan for Athens, 1833.

French francs was soon spent and ceased even to be serviced after 1843. The fiscal problems did not permit ventures such as the expropriation of the old town of Athens to conduct excavations, the construction of buildings for public use, or even the commissioning of maps of the country by the competent authority etc. The latter was a typical example of the failure of state planning: the Public Economy Office in the Secretariat (Ministry) of Domestic Affairs was established in order to record topographical, population and economic data systematically. ${ }^{10}$ It was abolished in 1846 and re-established in 1859 with different duties, commercial and industrial.

Town planning was influenced by the lack of opportunities to plan spaces for public use and public welfare. The lack of public land available for town planning purposes was its main feature, leading to planning with limited public space. The problem with public finances did not permit funds to be made available for purchasing land or paying land owners. At the same time, the problem of public finances led to the handling of available national land with thrift, owing to its being legally bound: the term national land was used sparingly because of its legal obligation: the term national land (McGrew, 1985) was used to describe the total of Muslim properties that were expropriated by revolutionary governments during the struggle for independence. These revolutionary governments had negotiated a loan in London, with the national lands being used as security for the loans of 1824-25, and created difficulty in their handling. The great cost of borrowing (Kofas, 1981) and the economic difficulties of the new Greek state led to the ceasing of repayments in 1827. After payments ceased, European bond-holders exerted pressure periodically, asking Greece to pay them back by selling off national lands. For many decades, these debts prevented Greek gov${ }^{10} \mathrm{GG} 18,1834$. 
ernments from handling the national lands freely. The distribution of national lands was of concern to Greek society throughout the entire nineteenth century. In any event, national land was utilized to create new cities, new towns.

National lands were both various buildings (mosques, shops, houses, mills, olive presses, inns etc.) and lots (crop land, farms, pasture land, salt marshes, forests etc.). These two categories of national lands were treated differently by the state: it was possible to sell the first. The state tried through sales to ensure the maximum income, that would relieve the dead end of constant public spending. National land in cities gradually became private land, owing to the public needs of the state, which led to either its sale by auction, or its free assignment to serve social policy needs for special categories of citizens, such as the old soldiers or their descendants, etc. The public economy problem obliged the state to use the national land as it became available, depriving cities and provinces of public spaces. In particular, the new capital, Athens, was built on private land, as the opportunity was given to departing Muslims to sell their properties (Drikos, 1994). And in the case of Athens, the economic difficulties played a decisive role: the efforts by Kapodistrias to borrow money in order to purchase land from departing Muslims and use it as public land were not successful. There was virtually no public land on the surface covered by the Athens town plan, a fact that influenced its urban development (Monioudi-Gavala, 2017).

\section{Extensions of Cities and Reconstruction as Tools of Economic Development}

The new Hellenic state began its historic course with settlements that had been destroyed by events in the Greek war of revolution. Very few towns escaped destruction (Nafplio, Navarino, Methoni and Koroni in the Peloponnese, Halkida and Karystos on Euboia, Lamia, Vonitsa and Naupaktos in Sterea Ellada). On the contrary, all the remaining settlements (Tripoli, Argos, Corinth, Aegio, Kalavryta, Patras, Pyrgos, Andritsaina, Kyparisia, Kalamata, Mystras and Gythio in the Peloponnese, Messolonghi, Karpenisi, Agrinio, Amphissa, Galaxidi, Atalanti, Livadeia, Thebes, Megara and of course Athens, in mainland Greece) were found in ruins (Manitaky, 1866: pp. 14-15). Of the twenty three devastated cities that were rebuilt and the ten new cities that were constructed between 1833 and 1866, Manitaky, a Greek engineer, who was responsible for public works, estimated (Manitaky, 1866: p. 18) that approximately 36,000 homes were built, to house an average of eight inhabitants each, with a total capital investment of about 252 million drachmas. ${ }^{11}$ Cities were rebuilt by private initiative and with private capital (Figure 2). A typical example was the building of the new town in Ermoupoli on the island of Syros, as shown in the photograph. Ermoupoli was built by refugees from Chios and elsewhere, who sought refuge there after the Revolution began. The refugees made it a small but international center for transit and renewal, as well as a splendid neoclassical town. The construction of towns constituted a

${ }^{11}$ The drachma that was issued in 1833 by Otto laid the foundation of the Greek monetary system, with an equivalence that was set at 0.895 gold French francs. It was replaced in 2002 by the euro. 


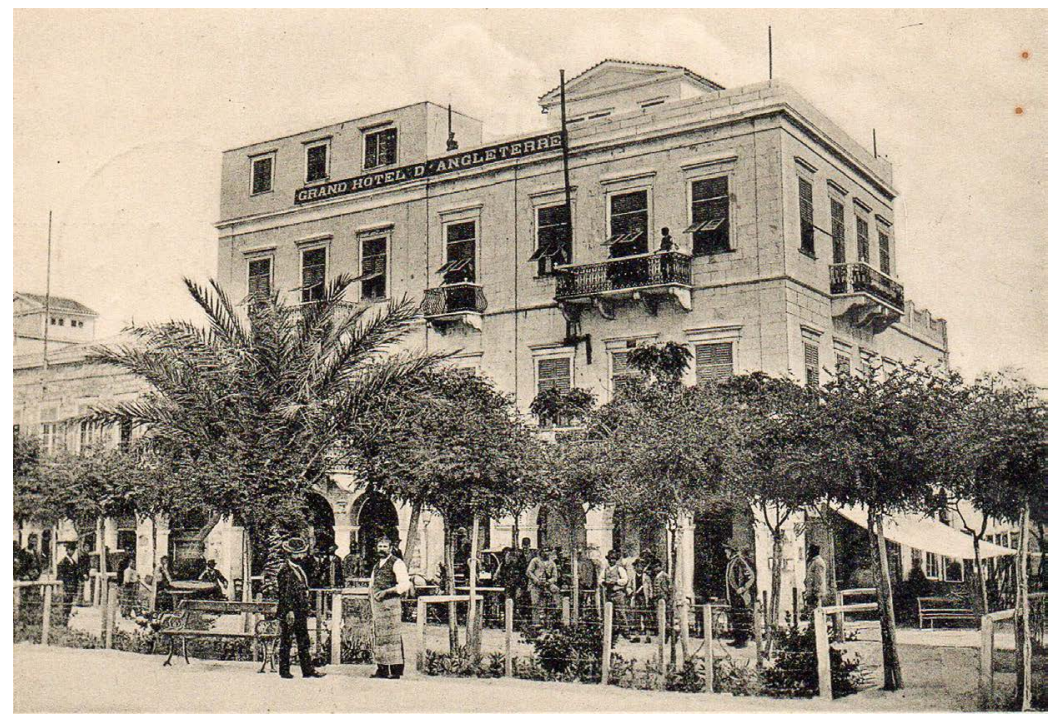

Figure 2. The modern face of newly-built Ermoupoli, Syros. The "England Hotel". National Historical Museum, Photography Archive.

significant linchpin of economic development, with investments in the land and real estate market that made it a strong competitor of industrial investments. The channeling of significant investment capital into the urban land market and into buildings by omogeneis, ${ }^{12}$ by local merchants, (who invested their profits from the sale of raisins), by high-ranking employees and by wealthy villagers was typical. Significant capital was invested in building houses in Athens by omogeneis and foreign residents who chose the new capital as their home. The image of the private houses confirms that their owners had significant funds and aimed for high aesthetics and construction value. The presence of their homes was intended to ensure their advancement in the society. Virtually all such homes, both in the capital and in other cities, were built with private funds. The state had a very limited participation in the re-construction. The improvement works covered the state's weakness regarding the amount owed to financial difficulties: both the magnificent buildings for public use in Athens (Kasimati, 2010; Kasimati \& Panetsos, 2014) and those for similar use in the regional cities (hospitals, schools) were built with contributions from benefactors, almost always in the neoclassical style (Biris \& Kardamitsi-Adami, 2004).

The plans that were approved during Otto's reign functioned as tools of economic development. Moreover, the text in the royal decrees approving the plans refers clearly to the goal of development. The state aimed at denser construction using development plans with regularity in organizing blocks of buildings and roads, in defining accurate boundaries on lots, usually with minimum dimensions of the façade and total area of the lot so that it could be built on, and the obligatory squaring of lots, promoted their creation (Monioudi-Gavala, 2017: ${ }^{12}$ Greek businessmen of the Ottoman Empire and the diaspora, were usually merchants, financiers, bankers, or ship-owners. They sometimes had more than one business activity. Some decided to settle in Athens, mainly during the second half of the nineteenth century, where philanthropic works were being carried out. 
pp. 31-32). Extending urban space by lots also influenced financial activity in another way. It changed farmland to lots, allowing farmers to invest in progress through the sale of land to small tradesmen in the cities and to services.

The reconstruction and transformations of constructed space were a goal in Otto's reign, since they were a visible confirmation of progress, as the city's image competed with that of Europe: cities were designed with regularity, with straight roads of standard width, with squares and trees around them (even in regional towns, surrounded by fields and not industries like the cities of the west). In the organization of the cities the "iconographic strategy" (Bastea, 2014) prevailed which was applied through the new geometric city planning, the new architectural morphology of neo-classicism, and the linguistic return to ancient place names.

On the contrary, there was an extended lack of planning and measure in public investments. During the early decades of the new Hellenic state, public investments participated very little in the gross domestic product. The state of infrastructure was seen as being in opposition to the impressive image of the reconstructed cities (Manitaky, 1866: pp. 15, 26-30). ${ }^{13}$ A limited program of public investments operated from 1850 to build infrastructure works (road and rail network), but mainly for Athens. Undoubtedly, during the period from the creation of the Hellenic state until 1880, there were insufficient public investments and infrastructure works (Synarelli, 1989). In the last decades of the nineteenth century, during the government of Charilaos Trikoupis (Tricha, 2001), significant infrastructure works were carried out through borrowing abroad. ${ }^{14}$ In the Greek state, infrastructure works were covered exclusively by the public purse, ${ }^{15}$ in contrast to handing over of projects to private businesses, which had been the case in the Ottoman empire.

Private ownership played a major role. The country's first Constitution, which was granted by Otto in 1844, after the revolutionary movement of $1843,{ }^{16}$ protected ownership. ${ }^{17}$ The relationship of the society with landed ownership had been very strong since the beginning of the new Hellenic state. And this relationship was not accidental: the state systematically favoured land ownership, which became a regulator of stability. The large and constant extensions of Athens and the other cities permitted the settlement of the population, the constant increase of which fed the demand for real estate. This great demand made ${ }^{13}$ The total network of the $461 \mathrm{~km}$. of national roads was built between 1833 and 1866, the longest parts of which were from Elefsina to Thebes $(48 \mathrm{~km}$.) and from Sparta to Gytheio $(47.5 \mathrm{~km}$.) providing a picture of the geographical isolation of some regions in the country. ${ }^{14}$ Charilaos Trikoupis dominated the political scene in Greece during the troubled 20 years between 1875-1895. Under his government, railways and road networks were built, the Canal of Isthmus of Corinth was constructed, etc.

${ }^{15}$ The major works from the period of Charilaos Trikoupis were built using money borrowed internationally. The inability to serve these loans ultimately led to bankruptcy.

${ }^{16}$ On 3 Sep. 1843 there was a popular uprising and a strike was called by the Athens guards after which the National Assembly was convened and approved Constitution in the following year. It was published in GG 5, 1844 .

${ }^{17}$ Article 12 of the Constitution stated that no one can be deprived of his property unless there is a public need, and that everything is done on the basis of the law with repayment afterwards. 
investment in land and real estate profitable, the value of real estate was constantly increasing, thereby ensuring profits and in many cases, rapid enrichment. The treatment of urban land by encouraging dense construction, intense rebuilding and the constant overvaluing of landed property, all fostered financial uncertainty for large groups of the population as well as social tensions. Real estate laid the foundation for financial security as early as the first decades of life in the new Hellenic state. At the same time, investment in real estate was essentially untaxed (Dertilis, 2009: p. 809). ${ }^{18}$ Until recently, Greece was one of the few countries in OEC that did not tax the ownership of real estate. Efforts to establish real estate taxation were limited, while in essence the first systematic taxation was imposed in 1975, without particular success owing to the problems of calculating these taxes.

The "love of building" (Monioudi-Gavala, 2017: pp. 41-54) was, from the outset of the modern Hellenic state, a characteristic of the Greek, who had been influenced by the recent financial crisis. Building was a one-way street in the direction of growth by utilizing the land, which became more intense later, during the decades after World War II and the Greek civil war, with broad reconstruction that resulted in replacing whatever remained of nineteenth century buildings.

\section{From the Pre-Revolutionary Model to the Uniformity of Urban Space}

When the new state was coming into being, a very small percentage of the population resided in urban areas. During the decades after the establishment of the new state, tens of thousands of rural population, or those who had moved from other regions, settled in cities, increasing their population by 94 per cent between 1833 and 1861 (Dertilis, 2009: p. 290). At the same time, the increase of the population as a whole was significant, from 719,000 inhabitants in 1833 to 2,187,000 in 1889 (Dertilis, 2009: p. 290). Greece's increased territory (1864, 1881) was certainly responsible for the increase in the total population, which was, however, mainly due to state initiatives regarding constructed space. During the 30 -year period from the 1830 s to the 1860 s, Athens grew as the capital city (Figure 3). In addition, the three port cities of Ermoupoli, Piraeus and Patras (Figure 4) were also laid out carefully, and became places in which the first industries were established. There were also regional cities and towns, which also evolved, but at a much slower rate: in Athens, the three main streets (Ermou, Athinas, Aiolou) were built immediately after the approval of the Kleanthis and Schaubert plan. On the contrary, the bazaar inherited from Ottoman Athens survived until 1880, when it was destroyed by fire. The application of "improvements" in existing sections of cities was delayed: the implementation of the Agrinio plan that was approved during the reign of Otto (1852-53) began thirty years after its approval (Monioudi-Gavala, 2010).

${ }^{18}$ Taxation was imposed on buildings as early as 1836 , at low rates, which increased only after 1887. It produced very little and it was not until the late nineteenth century that taxation began to produce somewhat more. 


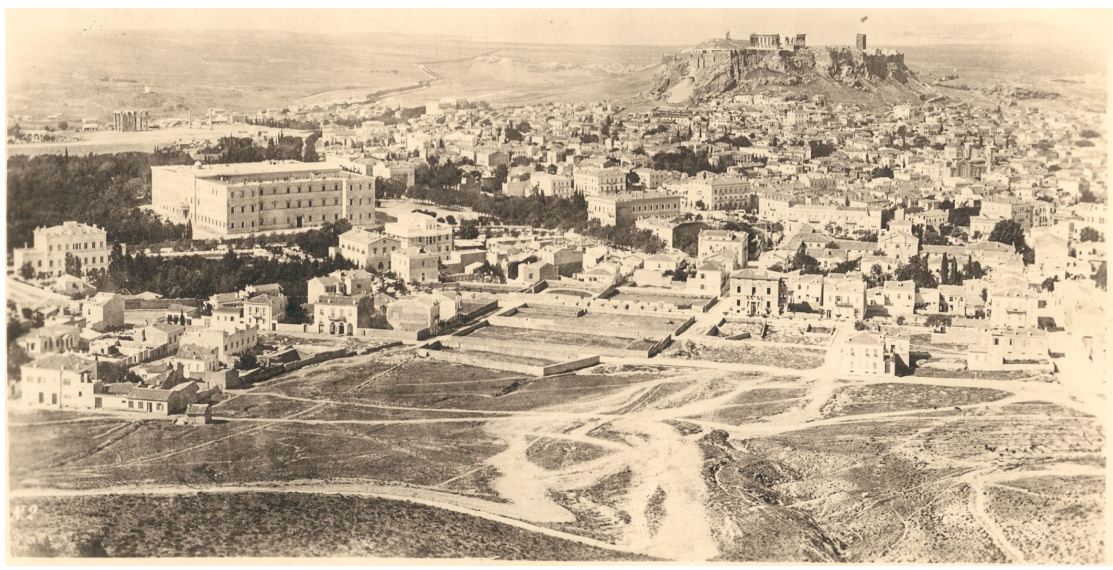

Figure 3. General view of Athens, from Lycabettus hill, in about 1874. In front is the new section of the city with straight streets and new buildings. The palace of Otto is dominant on the left. National Historical Museum, Photography Archive.

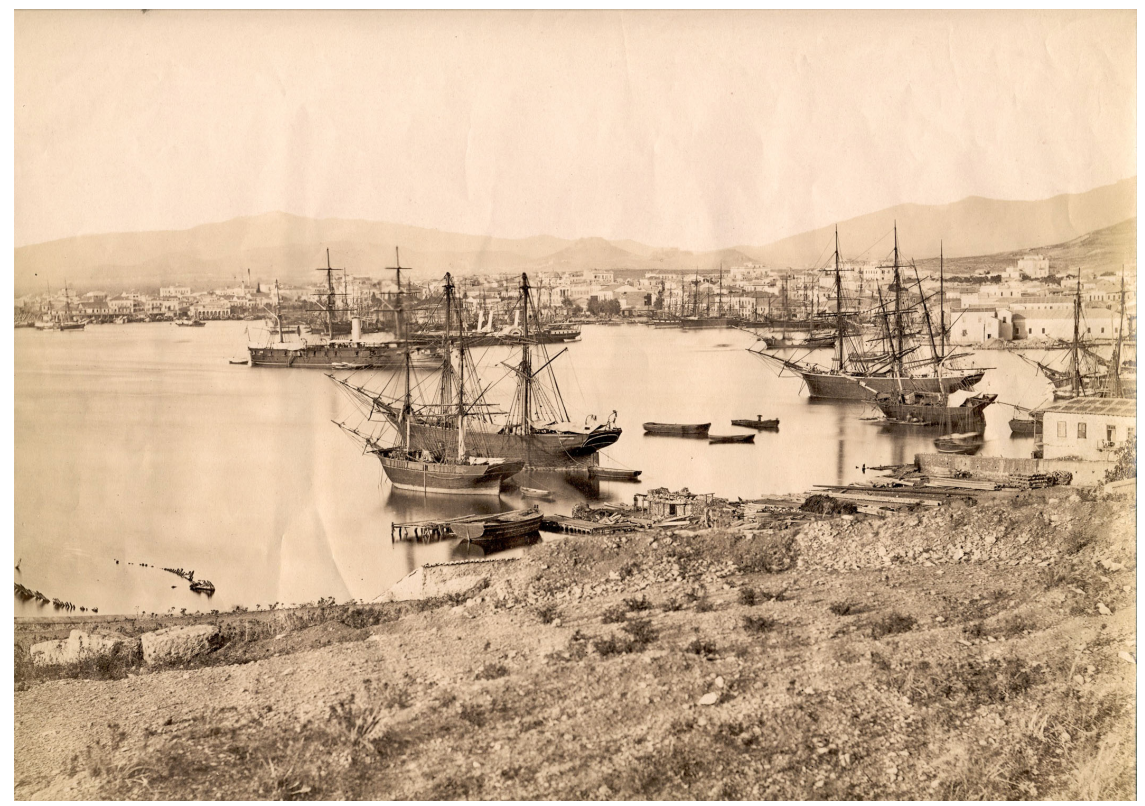

Figure 4. Piraeus, general view of the city. National Historical Museum, Photography Archive.

Despite state ambitions, changes in the cities during the first decades after the creation of the new Hellenic state took place slowly. Urban transformations evolved slowly until about 1880 , owing to the survival of pre-revolutionary models and the isolation of regions, owing to the lack of a communications network. Most settlements during this period were thus isolated and introverted, linked among themselves mainly through trade fairs, which sometimes coincided with local religious feasts. The image of the settlements reflected the geopolitical reality that they represented: the settlements of the Peloponnese, Roumeli or the Cyclades during the early decades after the creation of the new state were characterized by their local features, according to the conditions under which they were created. Their gradual change led to the uniformity desired by the state. 
The hierarchy was shaped during the time of Charilaos Trikoupis: the major works that were carried out then permitted the existence of connecting links between the various regions, which had not existed earlier (communications were conducted solely by sea during Otto's reign). The new transportation networks and their infrastructure changed the geographical entities or created new ones. The major public works of the Trikoupis period (Kostis, 2018) ${ }^{19}$ led to the network of urban centres organized around the nation state, and with the capital having greater control over the regions. It was not until the final decades of the nineteenth century that Greek cities were able to develop collaboration networks, but always centred on Athens.

However, overcoming the local peculiarities and shaping the constructed environment in a unified way throughout the country in the nineteenth century was delayed and never completed in regions on both the Greek mainland and its islands. A typical example is provided by the settlements throughout the Cyclades islands, a relatively long distance away, by the available means of transport from mainland Greece during that era. In shaping the built environment there, common law continued to prevail, ${ }^{20}$ as shaped over the centuries. The building regulations for the settlements in the Cyclades were under the jurisdiction of common law. They outlined mainly the limitations and prohibitions that the inhabitants had to apply to their buildings. Technicians were permitted to shape architectural features as part of the special environment of Cycladic settlements and to create an urban space that was simple and unique.

\section{Cultural Change on the Management of Constructed Space}

The changes experienced by the urban population during the early decades after the establishment of the state were on a very large scale. The pre-revolutionary model, which was inherited by the new state, preceded the Tanzimat reforms that had evolved during the Ottoman empire. Within a few decades, the inhabitants of the Hellenic state found themselves facing changes that could have been defined as cultural in the situation that had prevailed for centuries until then ${ }^{21}$. At its outset, the Greek state had isolated communities with different traditions. People whose identity was based on a network of their personal contacts within the boundaries of their regions were obliged to follow principles defined by a central administration that represented the nation. Institutions were transplanted from the western experience and imposed on a traditional society.

The regulation of matters regarding constructed space was the privileged field of state intervention, the competent bodies of which were organized in the context of centralization. Decisions were made centrally in Athens, the capital, and

${ }^{19}$ In 1883, the French Public Works Mission was established, which operated until 1895 and covered the whole country at the level of technical knowledge.

${ }^{20}$ One of the regular members of the Regency during the minority of Otto was von Maurer, according to whom common law included, apart from a variety of local customs, legal collections from the late Byzantine period, such as the Exavivlos. He recommended that it be retained, but his recall to Bavaria in July of 1834 put an end to his work.

${ }^{21}$ It is described in publications of the period (About, Bricebridge, Buchon, Finlay, Strong, etc.). 
specific state organs saw to their implementation. Decisions came from above and from the centre. Constructed land was subject to a "modernizing revolution" from above, with western-type regulations and structures imposed on a traditional population. This policy was later blunted by the creation of municipalities ${ }^{22}$ and the activation of town councils. Gradually, the municipal authority acted as intermediary between the central authority and the local community, thereby ensuring participation by the society (Monioudi-Gavala, 2012: pp. 209-211).

The transition from the pre-capitalist to the "modern" period in the mid-nineteenth century was associated with the view of a public space with a more "open" character. There was a change in the relationship of buildings with the city's public space: the appropriation of public land and its use as an extension of private land for buildings ceased (the image of the market changed, and extending shops onto the street was prohibited, as it was in the Ottoman city). The changes were large-scale: the traditional market (the bazaar) of the Ottoman city was replaced by the nineteenth century market complex. Building central markets in the cities was a basic concern of the state, frequently on national land yielded for this purpose, under the law of 1859 and the decrees that followed. Municipal markets were created in cities such as Ermoupoli, Argos, Piraeus, Galaxidi, Patras, etc.

Apart from the changes in the structure of space, the urban population had to deal with the financial obligations stemming from them. Given the state's inability to cover the expenditures entailed in the acquisition of public lands in cities, their inhabitants bore the cost. The state dealt with its economic inability by passing the appropriate legislation, determining expropriation and calculating the recompense as planning tools: using them solved the economic problem and regulated the differences between owners. Given the lack of public land, expropriation was provided as a mechanism for acquiring the space necessary to implement the plan (streets, squares). The state did not own public land but nor did it have the resources to carry out its plans. The policy of creating reserves of land, such as that in force in other European countries, was never applied in Greece. Also, in very few cases and after disasters, urban reforestation was applied, such as during the rebuilding of Thessaloniki after the fire in 1917 (Karadimou-Yerolympou, 1995). The lack of state funds which would have made possible the recompense of owners affected by the construction of buildings for public use and for the creation of extensive public spaces prevented the use of more effective building regulations mainly in the capital of Athens (Monioudi-Gavala, 2018).

It is an indisputable fact that urban development and architecture contributed to creating a feeling of national pride. The official state ideology that sought to create a national identity based on the ancient Greek past (Herzfeld, 1986), ${ }^{23}$ was ${ }^{22} \mathrm{Law}$ "Re composition of the Municipalities" GG 3, 1934. It was one of the first statutes of Otto's reign, defining the municipality, among many other matters, as responsible for issues surrounding "new buildings and urgent repairs".

${ }^{23}$ The orientation toward the West co-existed with the traditional identity of the Greeks. 
also channeled to the Greeks through urban planning and architecture. Manitaky describes the rebuilding of the country proudly: "When it emerged from the struggle for independence, Greece was literally a pile of ruins. Thirty years later we find 23 cities that were destroyed during the war and rebuilt anew ... 10 new cities, founded on sites that had been ancient cities or on new sites" (Manitaky, 1866: p. 17). The image of the rebuilt cities and the new buildings was proof of the progress that had been made.

The issues faced by the inhabitants could fall into two categories of cities, the existing ones and the new ones, or the new sections of cities, that were created as synoekismoi with special regulations. The inhabitants of the latter acquired properties based on the plan and known terms, in contrast with the inhabitants of the former, who experienced great changes and upsets. There were major changes in people's lives as regards the management of landed property.

Even though an effort had been made by the Otto's kingdom to take into account the pre-existing regulations for constructed space in the legislation it decreed, the new legislation with its generalizations and codifications nevertheless constituted a completely new reality. The new town planning and architecture introduced a new viewpoint, but without abolishing the site's earlier relations and traditions. In many regions, strong common law prevailed and survived even in the most isolated island and mainland regions. Clearly, the old world could not be abolished by laws and decrees. It co-existed with the new one, and this duality characterized the entire period.

There is a trend in the bibliography related to the issue of applying the plans of the period to explain the moderate application of these plans as an expression of the "unstable" and "undisciplined" Greek nature. There were, however, good reasons for these reactions. It is a fact that a new order was imposed on the land without taking the social reality into account. Through planning, a new order was imposed on the pre-existing organization of the traditional settlement. A conflict was created between the social and the geometric order on the land. Nevertheless, the generalized view of the plan's prestige as bearer of modernization contributed to its acceptance. Moreover, it was imposed using a variety of measures. The command in texts regarding the implementation of decrees approving plans is characteristic. The new statutory framework and plans were accompanied by threats of penalties that were included in all legislation. Frequently the refusal to accept state power was confronted with coercion, and in some cases the state imposed its regulations using even armed violence. Usually, however, the state was on the border between the desire to apply whatever had been decided and the reactions of the society, and concluded in a moderate application of the urban planning regulations. If the decrees were based on foreign legislation, the process of applying them was relevant to the local reality.

\section{Conclusion}

In the foregoing analysis, an effort was made to explain the planning successes 
and failures of the fledgling Greek state. The factors were outlined that made it possible to achieve these goals, as were those that hindered them. Likewise interpreted are the pre-revolutionary models that survived for several decades after 1830.

The Greek state aimed to create a "regular" and "healthy" city, a planned city, instead of the spontaneously shaped one that emerged during the years of Ottoman rule, a city that follows following cultural models and rejects the remains of Ottoman rule.

Athens was the model on which other Greek cities were built. The basic reason for repeating the manner in which Athens was built throughout the country was the legislation, which was uniform, with noteworthy continuity. Cities were planned on the basis of common principles, the decrees that regulated constructed space had a generalized application. The model buildings of Athens constituted a source of inspiration for buildings in other cities, quite a few of which were works by the same architects (Figure 5).

The society of the period proved that it could adapt to whatever it was asked to do as regards creating cities. Data in archives prove an impressive ability on the part of the urban population to adjust within just a few decades. The state also appeared to adjust to the messages of the society. The initial plans were adjusted so that they could be implemented. Despite similar planning, the expression of the societies' particularities, with their local issues and claims, led to shaping identity in the cities. Those created over approximately one century were the result of a gigantic, coordinated effort by the state, the municipalities and the local societies. Eventually the society, in its own way, found the golden mean between state ambitions and its own capabilities regarding the changes

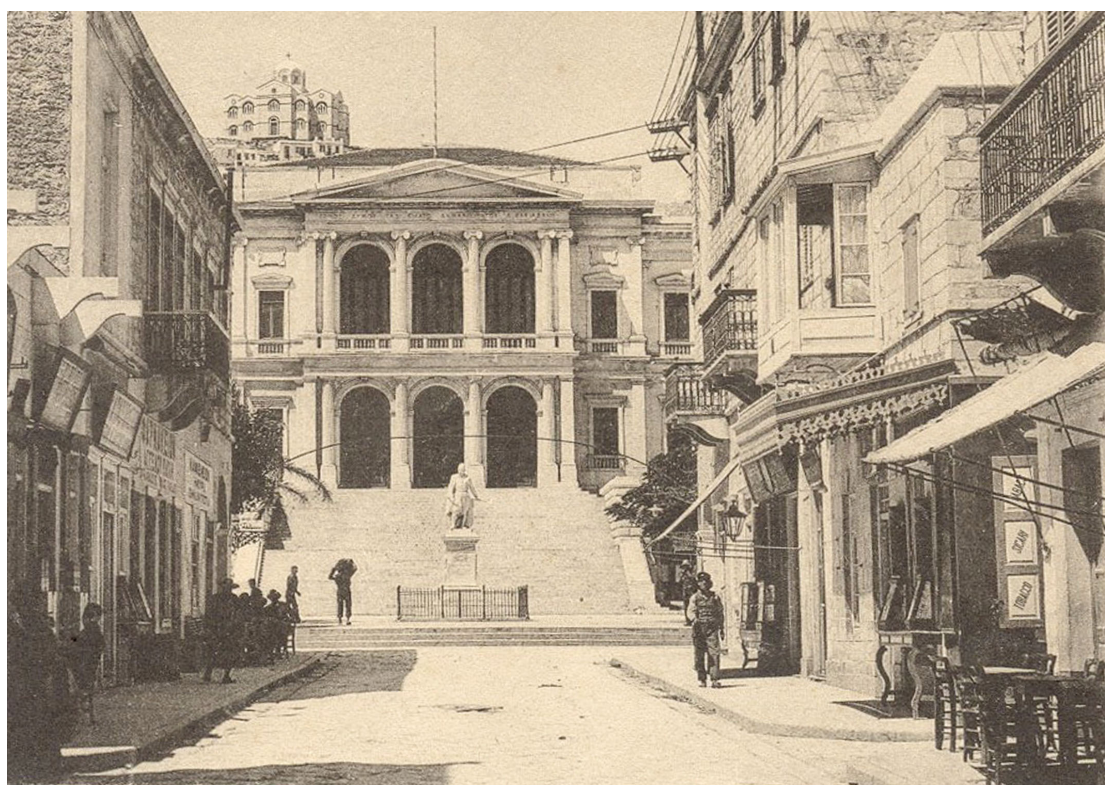

Figure 5. Ermoupoli, view of Ermou st. The centre is dominated by the City Hall (built in 1876-1898), a work by architect Ernst Ziller. National Historical Museum, Photography Archive. 
that it could accept. Communities became societies, the inhabitant became a citizen. The citizens adjusted, and the state was led to compromise through long-term processes.

\section{Conflicts of Interest}

The author declares no conflicts of interest regarding the publication of this paper.

\section{References}

Anastassiadou, M. (1997). Salonique, 1830-1912. Une ville ottomane à l'âge des Réformes. Leiden.

Aristarchi Bey, G. (1873). Legislation ottomane. Constantinople.

Bastea, E. (2000). The Creation of Modern Athens, Planning the Myth. Cambridge: Cambridge University Press.

Bastea, E. (2014). Athens 1890-1940: Transitory Modernism and National Realities. In J. Behrends, \& M. Kohlrausch (Eds.), Races to Modernity. The East European Metropolis, 1890-1940 (pp. 127-152). Budapest and New York.

Bikelas, D. (1868). Statistics of the Kingdom of Greece. Journal of the Statistical Society of London, 31, 265-298. https://doi.org/10.2307/2338853

Biris, K. H. (1966). Athens from $19^{\text {th }}$ to $20^{\text {th }}$ Century (In Greek). Athens.

Biris, M., \& Kardamitsi-Adami, M. (2004). Neoclassical Architecture in Greece. Athens: Melissa.

Dakin, D. (1973). The Greek Struggle for Independence, 1821-1833. Berkeley, CA: University of California Press.

Dertilis, G. (2009). History of the Greek State, 1830-1920 (5th ed.). (In Greek) Athens: Estia.

Diamandouros, N. (1972). Political Modernization, Social Conflict and Cultural Cleavage in the Formation of the Modern Greek State, 1821-1828. Ph. D. Thesis, New York: Columbia University.

Drikos, T. (1994). Land Sales of Muslims in Attica, 1830-1831 (In Greek). Athens: Trochalia.

Herzfeld, M. (1986). Ours Once More: Folklore, Ideology and the Making of Modern Greece. New York.

Kafkoula, K., Papamichos, N., \& Hastaoglou, V. (1990). City Plans in 19th Century Greece (In Greek). Thessaloniki: Aristotle University of Thessaloniki.

Karadimou-Yerolympou, A. (1997). Between East and West (In Greek). Athens: Trochalia.

Karadimou-Yerolympou, A. (1995). The Rebuilding of Thessaloniki (In Greek). Thessaloniki: University Studio Press.

Karidis, D. (2019). https://blod.gr/lectures/to-allo-shedio-tis-athinas-tou-1833

Karidis, D. N. (2014). Athens from 1456 to 1920. Oxford: Archaeopress.

Kasimati, M. (2010). Ernst Ziller (In Greek). Athens: National Gallery.

Kasimati, M., \& Panetsos, G. (2014). 'Hellenische Renaissance'. The Architecture of Theophil Hansen, 1813-1891. Athens: Theocharakis Foundation.

Kofas, J. V. (1981). Financial Relations of Greece and the Great Powers, 1832-1862. New 
York: Columbia University Press-East European Monographs Boulder.

Kostis, K. (2018). History's Spoiled Children: The Formation of the Modern Greek State. London: Hurst \& Co.

Llewellyn Smith, M. (1973). The Ionian Vision, Greece in Asia Minor, 1912-1922. London: Allen Lane.

Manitaky, E. (1866). Aperçu sur les progrès materiels de la Grèce. Athènes.

McGrew, W. W. (1985). Land and revolution in Modern Greece 1800-1881. The Transition in the Tenure and Exploitation of Land from Ottoman Rule to Independence. Kent, OH: Kent State University.

Monioudi-Gavala, D. (2004). The City of Chios, 1830-1940 (In Greek). Athens.

Monioudi-Gavala, D. (2010). Agrinio. Urban Planning Evolution (In Greek). Agrinio, Greece: Municipality of Agrinio.

Monioudi-Gavala, D. (2012). Urban Planning in the Greek State, 1833-1890. Agrinio, Greece: University of Western Greece.

Monioudi-Gavala, D. (2017). Planning and Landed Property in Athens, 1833-1922 (In Greek). Athens: Paraskinio.

Monioudi-Gavala, D. (2018). Creating a Metropolis: Construction Regulations in Athens, 1833-1864. In T. Slater, \& S. M. G. Pinto (Eds.), Building Regulations and Urban form 1200-1900 (pp. 271-287). London and New York: Routledge.

https://doi.org/10.4324/9781315570464-14

Papageorgiou-Venetas, A. (2000). Leo von Klenze in Greece (In Greek). Athens: Odysseas.

Papageorgiou-Venetas, A. (2001). Athens (In Greek). Athens: Kapon.

Pentzopoulos, D. (1961). The Balkan Exchange of Minorities and Its Impact upon Greece. Paris-Hague.

Petropulos, J. A. (1968). Politics and Statecraft in the Kingdom of Greece, 1833-1843. Princeton, NJ: Princeton University Press. https://doi.org/10.1515/9781400876020

Synarelli, M. (1989). Roads and Ports in Greece, 1830-1880 (In Greek). Athens: Hellenic Industrial Development Bank, Cultural Foundation.

Travlos, I. (1960). Urban Planning Evolution of Athens (In Greek). Athens: Kapon.

Tricha, L. (2001). Charilaos Trikoupis et les travaux publics. Athens: Kapon.

Tsiomis, Y. (2017). Athènes à soi même étrangere. Naissance d'une capitale néoclassique. Marseille: Parenthèses.

Yerolympos, A. (1996). Urban Transformations in the Balkans, 1820-1920. Thessaloniki: University Studio Press. 